\title{
Genetics and Education: Recent developments in the context of an ugly history and an uncertain future
}

\author{
Daphne Martschenko 1 \\ Sam Trejo 2 \\ Benjamin W. Domingue 2
}

1. University of Cambridge Faculty of Education

2. Stanford Graduate School of Education

Authors contributed equally. They can be contacted at

DM:

dm660@cam.ac.uk,

5307 South Ellis Avenue Apartment 1W Chicago, IL 60615

5712636650

ST:

samtrejo@stanford.edu

520 Galvez Mall Rm 409; Stanford, CA 94305

5128048185

BWD:

bdomingue@stanford.edu.

520 Galvez Mall; Stanford CA 94305

6507257393

\section{Acknowledgements}

We would like to thank Anna Vignoles, Jeremy Freese, Catherine Bliss, Sean Reardon, and Jason Boardman for comments. We would also like to thank Eric Turkheimer and three anonymous reviewers for their thoughtful critiques of an earlier version of this manuscript. This work has been supported by the Russell Sage and the Ford Foundations (96-17-04), the National Science Foundation Graduate Research Fellowship Program (DGE-1656518), and by the Institute of Education Sciences (R305B140009). Any opinions expressed are those of the author(s) alone and should not be construed as representing the opinions of funders. 


\title{
Genetics and Education: Recent developments in the context of an ugly history and an uncertain future
}

\begin{abstract}
Driven by our recent mapping of the human genome, genetics research is increasingly prominent and beginning to re-intersect with education research. We describe previous intersections of these fields, focusing specifically on the ways they were harmful. We then discuss novel features of genetics research in the current era with an emphasis on possibilities deriving from the availability of molecular genetic data and the proliferation of genome-wide association studies. We discuss both promises and potential pitfalls resulting from the convergence of molecular genetic research and education research. The floodgates of genetic data have opened. Collaboration between those in the social and hard sciences; open conversation among policy makers, educators, and researchers; and public engagement will all prove critical for enacting regulations and research designs that emphasize equity.
\end{abstract}

Keywords: genetics, education research, adversarial collaboration, equity, molecular genetics, polygenic score 


\section{Introduction}

Suppose it's the year 2025. You are a school administrator responsible for making decisions regarding the allocation of educational resources. A parent comes to your office concerned about their kindergartener; their family doctor has suggested that the child has a genetic makeup that indicates they are at high risk for developing dyslexia in a few years' time. This parent worries their child will start falling behind in reading soon; indeed, dyslexia diagnoses typically occur too late for optimal interventions (OzernovPalchik \& Gaab, 2016). Thus, the parent requests that learning supports (e.g., one-on-one reading coaching with a teacher's aide) are put in place immediately. Resources are scarce, but you want to ensure that every student has the best opportunity for learning. Is this a reasonable request? How well do genes predict dyslexia? Is prediction of equal quality for children from marginalized groups? What do you do?

While research into appropriate answers to these questions is still underway, we think that it is important for educators to begin to contemplate them. The field of genetics is going to affect education and, as a consequence, education research. Given the sudden ubiquity of genetic data and the great public interest it has garnered, we believe this is

inevitable. The scenario described above — the diagnosis of learning disabilities — seems a likely candidate for the intersection between the two fields given that many learning disabilities involve a medical diagnosis. However, as we discuss, there are other potential points of intersection including the use of genetic predictors to study a range of nonmedicalized human behaviors and conditions.

Discourses involving genetics are not altogether new to education. Arguments about genes, cognition, and group differences, for example, were prominent in the latter 
half of the 20th century (e.g. the debate surrounding "The Bell Curve" (Devlin, Fienberg, Resnick, \& Roeder, 2013; Heckman, 1995; Herrnstein \& Murray, 2010; Jencks \& Phillips, 2011; Neisser et al., 1996)) and have re-surfaced recently in popular media (Harris, 2017; Kahn et al., 2018; Klein, 2018; Reich, 2018; Saletan, 2018; Turkheimer, Harden, \& Nisbett, 2017). Much of the recent interest is driven by our rapid accumulation of vast amounts of molecular genetic data and the possibilities associated with such data. Whether the re-emergence of genetics as an issue in education makes one optimistic, worried, or downright nauseous, it is important to understand both the historical contexts of this debate and the present reality that, we argue, makes the return of genetics to education imminent.

We address both of these issues herein, starting with the ugly history of genetics in education research before turning to the current wave of molecular genetics research. Whether this iteration of research will produce positive or negative effects on the lives of children, whether it will lead to better opportunities and outcomes for all students: these are difficult questions. Indeed, we have divergent views on these issues. We consider this paper to be a form of 'adversarial collaboration' (Kahneman, 2003), driven by a desire to leverage our internal disagreements into a dialogue that can help inform the broader field. Such adversarial collaboration —in which individuals trained in different, even opposing, research traditions partake in a joint research effort — may yield benefits as it requires skeptics to engage with each other. In this spirit, our overarching goal is to help build an avenue for constructive conversation between the biomedical and social sciences rather than to further contentious debate between the two sides. We think the subject of genetically informed research in education is of sufficient importance that more in the 
education research community should be aware of both the historical precedents and contemporary realities of this branch of scientific and social inquiry. This paper is an attempt to cover such ground.

We focus on the availability of molecular genetic data and the proliferation of genome-wide association studies (GWAS). Given the centrality that prediction from molecular genetic data plays in this paper, we note at the outset key caveats that the reader should bear in mind. Genetic effects on educationally-relevant outcomes or behaviors need to be relatively large to have practical relevance. Currently, the fraction of variation explained by polygenic prediction in hold-out samples is modest but growing (Cesarini \& Visscher, 2017). We write under the assumption that genetic predictors are sufficiently predictive to be useful for scientific inquiry, but not necessarily for 'clinical' use; we argue that this is reasonable given the predictive power of recent work (Lee et al., 2018). Genetic effects of this size will likely entail questions about genetic determinism, essentialism, racism, and/or classism with respect to their application. We spend a great deal of time on these issues and pay special attention to the particulars of molecular genetic data. This focus is warranted given the sudden proliferation of this type of data and the attendant public interest. However, it is not meant to minimize research in related fields that utilize alternative forms of genetic data such as twin studies (Asbury, Almeida, Hibel, Harlaar, \& Plomin, 2008; Asbury, Dunn, \& Plomin, 2006) or even other types of biological data such as epigenetic studies (Gulson \& Webb, 2018; Linnér et al., 2017; Pickersgill, Niewöhner, Müller, Martin, \& Cunningham-Burley, 2013).

We proceed as follows. In Section 2 we describe the ugly history of how bigoted ideologies combined with genetically-informed research to bolster prejudiced policies in 
the United States (repugnant views can, of course, still be found today (Rosa \& Bonilla, 2017)). In Sections 3 and 4, we turn to the emergence of molecular genetic data and discuss its use in education research. In Sections 5 and 6, we discuss ethical and practical problems in this rapidly growing field, noting some of the most challenging issues, and end by providing actionable recommendations.

\section{Genetics and Education Prior to the Molecular Age}

We focus on two crucial features of earlier intersections between education and genetics. First, we highlight the eugenic and essentialist discourses that surrounded genetics, intelligence, race, and class in the $19^{\text {th }}$ and $20^{\text {th }}$ centuries. We focus on the pernicious implications that people drew from specious equating of genotype (an individual's unique set of genes) with phenotype (an observable trait or behavior), focusing specifically on arguments involving the supposed normative superiority of certain groups. Next, we discuss scholarship from more recent eras including the limitations of heritability estimates and the problems of a first wave of studies that used small quantities of molecular genetic data to advance bold claims.

\section{2a. Genetics and Group Differences}

The use of genetic language to describe racial and socioeconomic differences in cognitive ability and academic performance was commonplace in the $19^{\text {th }}$ (Galton, 1869 ; Hunt, 1864) and 20th centuries (Jenkins, 1939; Jensen, 1968, 1970; Shockley, 1971) and continues today (Wade, 2014). Intelligence testing was a frequent locus for such discourse. Between 1890 and 1920, dozens of intelligence tests were developed in Europe and America that claimed to offer robust measures of intelligence (Binet, 1913; Terman, 
1916). The observation that individuals from different racial and socioeconomic groups have tended to perform differently on intelligence tests has caused great controversy (Rushton \& Jensen, 2006).

Many hypotheses for these findings have been advanced. One hypothesis has minimized the salience of such findings by pointing to the stark socioeconomic disparities between groups (Heckman, 2011) as well as questioning whether such tests are valid across cultures (Greenfield, Ward, \& Jacobs, 1997; Sternberg \& Grigorenko, 2004). An alternative hypothesis suggests that differences are largely due to differences in biology across the relevant groups (Jensen, 1969; Shockley, 1971). This latter view is unsettling for a number of reasons, including its potential echo of old arguments that such biological differences will undermine attempts to improve human wellbeing through social policy. Or, even worse, that such differences justify punitive policies. Ability testing was used directly to resist desegregation (Mayo, 1913) and immigration (Brigham, 1922), and generally validate socioeconomic (Galton, 1891) and racial inequalities (Shockley, 1972). A return to such views would be the most distressing outcome of the increased salience of genetics in popular and scientific discourse; some argue that it is already happening (Gillborn, 2016).

\section{2b. The Study of Heritability}

Dating back to the late $19^{\text {th }}$ century (Galton, 1869), many discussions of genetics have revolved around the concept of heritability, the proportion of observed variation in a trait associated with genetic variation. Heritability can be estimated by comparing a trait's correlation amongst identical twins to its correlations amongst fraternal twins (Visscher, Hill, \& Wray, 2008) since identical twins are genetic copies of each other 
while fraternal twins are biological siblings that share only about half of their genes. Strikingly, identical twins are far more similar than fraternal twins on practically every observable characteristic, ranging from height to more complex traits like educational attainment (Polderman et al., 2015); this is taken as evidence for the pervasive heritability of nearly all traits, the "first law" of behavioral genetics (Turkheimer, 2000). Outcomes of interest to education researchers are no exception; cognitive ability (Polderman et al., 2015), attention deficit-hyperactivity disorder (Dalsgaard, Østergaard, Leckman, Mortensen, \& Pedersen, 2015; Franke et al., 2012), and dyslexia (Byrne et al., 2009; Soden Hensler, Schatschneider, Taylor, \& Wagner, 2010) are all highly heritable, with meta-analysis showing that genes explain roughly half the variation between individuals. However, from the perspective of education research, a key limitation of heritability findings is that they have relatively little to say about the effects of educational environments (Turkheimer, 1991)-the bread and butter of education research. This is an important caveat. That said, others (e.g., Harden, 2018) have argued that genetic studies could offer valuable information to education research that may be lost if genetic research is prematurely dismissed; much of the remainder of this paper is an attempt to describe both why this might be as well as the problems associated with such research.

As a general rule, heritability need not be constant across time and place (Feldman \& Lewontin, 1975) and may in fact be intimately linked to environmental context. A particularly salient example for our purposes involves the heritability of cognitive functioning. It has been argued that its heritability is larger in high SES households compared to low SES households in the United States (Scarr-Salapatek, 1971; Turkheimer, Haley, Waldron, D’Onofrio, \& Gottesman, 2003). While the empirical 
evidence for this argument has been mixed (Figlio, Freese, Karbownik, \& Roth, 2017; Tucker-Drob \& Bates, 2016), we note that the possibility of such interplay between genetics and environments emphasizes the importance of accounting for environmental context when attempting to understand genetic influences. Such concerns are at the fore in contemporary thinking about study designs that include genetic data (Boardman, Daw, $\&$ Freese, 2013).

Although studies of heritability have demonstrated that nearly all human characteristics are influenced by a person's genetics, heritability estimates leave much to be desired in terms of the information they provide regarding social policy. Decomposing the variation of a trait into its "genetic" and "environmental" components provides almost no relevant information with regards to the efficacy and efficiency of different interventions. In fact, many highly heritable traits are readily influenced by policy. As the economist Arthur Goldberger famously pointed out, distributing eye-glasses to treat myopia would likely pass a cost-benefit analysis with flying colors, even if myopia was $100 \%$ heritable (Goldberger, 1979). On the other side of the coin, many traits with relatively low heritability estimates, such as religiosity (Polderman et al., 2015), would not appear to be particularly actionable as targets of social policy. Thus, findings from research focusing on heritability estimation may have limited practical utility. The study of human genetics leaves undiminished the need for well-crafted social policy.

\section{2c. The Candidate Gene Era}

Previously, the social sciences were limited in their ability to engage with human biology due to one hugely important limitation. Genes, the fundamental biological building block, were largely invisible to scientists until the end of twentieth century. 
Concordant with the completion of the Human Genome Project (Lander et al., 2001), relatively limited quantities of genetic information began to be available for social scientific inquiry. Hoping to move beyond simple heritability estimates and towards exploration of relationships between specific genetic variants and a variety of outcomes, scientists began conducting what have come to be known as "candidate gene" studies using these limited amounts of molecular genetic data. These studies involve selecting a small set of genetic variants, typically fewer than ten, a priori based on their presumed biological function (hence "candidate genes") and examining their association with a particular trait.

From the late 1990s into the 2000s, scientists linked candidate genes to outcomes ranging from antisocial behavior (Caspi et al., 2002) and ADHD (Payton et al., 2001) to music aptitude (Ukkola, Onkamo, Raijas, Karma, \& Järvelä, 2009) and political participation (Fowler \& Dawes, 2008). Due to the high cost of processing genetic information during the candidate-gene era, these studies largely relied on samples of a few hundred participants. As a consequence of the small samples and other methodological failings that were not well understood at the time, research linking candidate genes to human behavior was plagued by false positives and replication failures. Though many peer-reviewed studies described statistically significant associations between candidate genes and a variety of traits, the vast majority of these associations failed replication tests (L. E. Duncan \& Keller, 2011; Gizer, Ficks, \& Waldman, 2009; Ioannidis, Ntzani, Trikalinos, \& Contopoulos-Ioannidis, 2001) leading, in at least one case, to heightened editorial scrutiny for such work (Hewitt, 2012). For example, of 12 genetic variants with published associations with general intelligence, 
none replicated in follow-up work (Chabris et al., 2012). As a result of these problems, newer methods have emphasized replication and statistical power in attempting to link individual genetic variants to phenotypes of interest.

\section{The Genomic Era}

Today, we are witnessing a new phase of biological inquiry into human behavior. The cost of DNA sequencing is decreasing at breakneck speed (National Human Genome Research Institute, 2016) and great advances have been made in analytic methods for the processing of large amounts of genetic data. Perhaps the most impactful development in recent years is the genome-wide association study (GWAS). A GWAS probes the relationship between a trait and regions of the genome using large datasets containing individual-level information on genotype and phenotype (Pearson \& Manolio, 2008). GWAS relies upon the recent availability of DNA from tens to hundreds of thousands of individuals and looks to identify variants of single-nucleotide polymorphisms (SNPs) that are more common in people exhibiting a given trait of interest. SNPs are the most common form of human genetic variation and represent a mutation at a single locus in the genome; a typical GWAS will involve analysis of millions of SNPs.

We emphasize one key theme from this first decade of the GWAS literature (Visscher, Brown, McCarthy, \& Yang, 2012; Visscher et al., 2017). This approach has started to reveal a core similarity across many traits. It has become clear that many traits are affected by a large number of SNPs with each SNP having only a tiny effect on the trait (Boyle, Li, \& Pritchard, 2017; Chabris, Lee, Cesarini, Benjamin, \& Laibson, 2015). Put another way, the heritability of most behavioral outcomes is due to a large number of genes rather than a small number or even just one gene. Traits that have this quality, 
including both anthropometric and behavioral outcomes as well as many common diseases, are known as 'complex traits' to differentiate them from simpler Mendelian traits, such as cystic fibrosis and Huntington's disease. As one consequence, findings from GWAS of such complex traits are frequently used to generate a single predictor, a "polygenic score" (Dudbridge, 2013), meant to summarize all the identified genetic information pertaining to a particular trait given that the genetic influence on a trait is dispersed so widely throughout the genome. Much of the following section involves discussion of studies that have utilized such scores.

\section{Molecular Genetics and Education}

So, what do these recent developments have to do with education? We are not alone in trying to answer this question. The past five years have seen increased calls for incorporation of genetic information into education (Asbury \& Plomin, 2013; Kovas, Tikhomirova, Selita, Tosto, \& Malykh, 2016) leading to debate over the relevance of this research to educators (Asbury, 2015; Panofsky, 2015; Sabatello, 2018; Thomas, Kovas, Meaburn, \& Tolmie, 2015). Similar discussions are occurring in related disciplines (Conley, 2016; Freese, 2018). Those advocating for the incorporation of geneticallyinformed research into educational practice discuss the promise of "personalized" education (Asbury \& Plomin, 2013) and see integrating genetics into education research as a way to optimize educational processes (Kovas et al., 2016). An alternative perspective focuses on the broader possibilities of "biosocial education" (Gulson \& Baker, 2018; Gulson \& Webb, 2017, 2018; Youdell, 2017), a framework for education practice focusing on the potential of inclusion of biological information—-from fields such as epigenetics (Youdell, 2017, 2018) or neuroscience (Immordino-Yang, Darling- 
Hammond, \& Krone, 2018; Williamson, Pykett, \& Nemorin, 2018)—in an attempt to enrich understandings of students and their learning.

We focus specifically on the implications of increased availability of molecular genetic data for both education and education research. In the following sections, we briefly discuss what we've learned about the genetics of education-related phenotypes via GWAS, how these genetics have been followed up in polygenic score studies, and potential techniques through which researchers argue such data may be used to improve the practice of education. We do not attempt a comprehensive review; rather, we aim to provide a concise overview of the relevant findings and methods.

\section{4a. GWAS of education-related traits}

Twin studies have long suggested that educational attainment, defined as the years of schooling a person receives, is heritable (Branigan, McCallum, \& Freese, 2013). The first GWAS probing the genetic influences of educational attainment was published in 2013 (Rietveld et al., 2013). Three years later, the same core team of researchers (Okbay et al., 2016) increased their sample to roughly 300,000 individuals and published a follow-up GWAS identifying 74 genetic loci significantly related to years of schooling. Recently, a third generation educational attainment GWAS, based on over one million individuals, identified over one thousand genetic loci associated with years of schooling (Lee et al., 2018). The genetic variants identified in these studies are associated with plausible biological mechanisms, e.g., a variety of processes in the central nervous system. In a similar vein, there have been several studies examining the genetics of cognition (Hill, Davies, McIntosh, Gale, \& Deary, 2017; Sniekers et al., 2017; Trampush et al., 2017; Zabaneh et al., 2017). 
Researchers have also learned about the genetics of traits whose development is highly salient to educators like cognitive ability (Sniekers et al., 2017) and ADHD (Demontis et al., 2017). Follow-up work focusing on individual genetic variants may be of interest in some cases, but we suspect that genetic predictors that aggregate information, such as polygenic scores, will be of greater interest given the small predictive utility of each individual variant. Polygenic scores are beginning to have sizable predictive power. For example, the polygenic score derived from the most recent educational attainment GWAS (Lee et al., 2018) explains roughly $12 \%$ of the variation in years of schooling and $9 \%$ of the variation in cognitive ability. By way of comparison, this is on par with that of parental education or individual cognition, two widely used predictors used to further our understanding of educational processes in the social and psychological sciences.

\section{4b. GWAS Follow-up}

What, precisely, are genetic discoveries related to educational attainment capturing and in what contexts do they apply? How is it that new polygenic scores predict educational attainment roughly as well as our best existing social and psychological measures? Are these studies identifying genes that influence cognition? Presumably so, but evidence suggests other influences as well (Krapohl et al., 2014). What about appearance? Personality and socioemotional skills? Or, more distressingly, are these findings driven by genes that simply map onto existing patterns of social stratification? Work on these questions is ongoing. Below we offer a brief summary of what we know thus far (for an alternative perspective, see (Cesarini \& Visscher, 2017)). 
A large number of genetic variants identified in these studies play a role in various stages of brain development, both prenatally and over the life course (Okbay et al., 2016). Polygenic scores constructed based on GWAS results have been shown to associate with phenotypes directly linked with educational attainment including school performance (Selzam et al., 2016), increased verbal ability in childhood (D. W. Belsky et al., 2016), personality (Mõttus, Realo, Vainik, Allik, \& Esko, 2017), and learning disabilities (de Zeeuw et al., 2014). They are consistently predictive of both educational and occupational attainments across a variety of school contexts (Trejo et al., 2018). They are increasingly being tied to more distal phenotypes such as longevity (Marioni et al., 2016) and smoking (Wedow et al., 2018).

While follow-up studies have given us some sense of the characteristics of people that are associated with the educational attainment polygenic score, a more fundamental question is whether these studies have merely detected genetic variants associated with social class. Polygenic scores constructed from these GWAS results are indeed associated with family home environment (D. W. Belsky et al., 2016; Conley et al., 2015; Krapohl \& Plomin, 2015) and neighborhood socioeconomic status (D. W. Belsky et al., 2018; Domingue, Belsky, Conley, Harris, \& Boardman, 2015). However, even after controlling for socioeconomic origin (which we know to be associated with educational attainment), these polygenic scores predict changes in an individual's socioeconomic standing over the life course (D. Belsky et al., 2018). Moreover, siblings with higher scores tend to accrue more years of educational attainment than their co-sibling, suggesting that the polygenic score is not entirely confounded by family background (D. Belsky et al., 2018; Domingue et al., 2015). These findings suggest that such scores may be useful in future 
research as indicators of individual difference; we discuss this in detail in the following section.

Although the evidence suggests that polygenic scores are potentially useful indicators of individual-level characteristics, they need to be used and interpreted with care. Consider recent findings of "social genetic effects" (Domingue \& Belsky, 2017). In an examination of friends and schoolmates, the observation was made that the genetics of these social peers are both correlated with one's own genetics and also predictive of one's outcomes net of their own genes (Domingue et al., 2018). A related example comes from an examination of parental genetics. A mother's genotype is associated with an

offspring's attainment (Bates et al., 2018; D. Belsky et al., 2018; Kong et al., 2018) net of the offspring's genes. Such findings make it hard to separate 'nature' from 'nurture'. These associations between genes and environments complicate simple interpretations of results involving this genetic predictor.

\section{4c. Using molecular genetic studies to improve education research}

Now that evidence has begun to accumulate suggesting that polygenic scores are valid predictors of individual difference, how might such scores be utilized in education research? We focus on discussions of several approaches that are methodologically tractable for non-geneticists and consistent with existing analytic approaches in quantitative education research. In particular, we discuss utility in understanding individual development as well as the design and analysis of interventions (or other types of exogenous shocks). Crucially, the possible applications we discuss below do not involve 'precision education' (using individual genotype to tailor educational services to a child); instead, they involve using genetic information to form a better understanding of 
how educational processes, both within an individual and a society, might contribute to positive educational outcomes.

Given that an individual's genotype is established at fertilization, a polygenic score can be used as a fixed point from which to observe child development (D. Belsky \& Israel, 2014). This design has been used to show that individuals with higher polygenic scores begin to differentiate themselves early in the life-course from lower-scored peers on dimensions related to language ability, but not other important developmental milestones (D. W. Belsky et al., 2016). Information obtained along these lines may ultimately be useful for the design of interventions to improve learning for all students (D. W. Belsky, Moffitt, \& Caspi, 2013) as they can help us identify the specific processes that are most germane to downstream outcomes of interest. Additionally, the use of polygenic scores may improve our understanding of intervention pathways by reducing confounding. Both biological and social endowments are passed down from parent to child. By using polygenic scores as a control variable in work studying intergenerational processes, researchers could be better able to understand the causal relationship between social factors and educational attainment.

Polygenic scores may offer a useful mechanism for better understanding responses to educational interventions. For example, recent work has used the polygenic score for educational attainment to emphasize changes in association between genotype and phenotype after the decline of Soviet rule in Estonia (Rimfeld et al., 2018), in different retirement saving regimes (Barth, Papageorge, \& Thom, 2018), and (using a polygenic score for BMI) to demonstrate the effect of mandatory schooling on health (Barcellos, Carvalho, \& Turley, 2018). Findings from these studies support the concept 
that social policies which reduce choice - in the case of mandatory schooling laws in the UK, for example - also reduce the salience of genotype. They may also be useful in the study of heterogeneous response; polygenic scores can be used to test hypotheses related to why (otherwise similar) people respond differently to interventions. Genetic predictors have already been used to understand differences in literacy skills and response to intervention (Kegel, Bus, \& van IJzendoorn, 2011); as their predictive power increases, so might their utility in this regard. Finally, others have noted that the availability of genetic predictors may increase the power associated with randomized controlled trials, potentially shrinking the costs associated with such research (Rietveld et al., 2013, see p. 28 of SI).

\section{Focal Issues}

While the previous section considered some possible avenues through which molecular genetic data may advance education research, there are also a variety of issues that complicate the degree to which such advances will be equity-promoting. In the following sections, we outline specific foci that merit attention as molecular genetic data becomes increasingly relevant in both the scientific and public spheres.

\section{5a. Human history and genetic diversity}

Human history is deeply intertwined with our genome. Examples abound; genetics can provide us information about patterns of immigration in the US (Han et al., 2017), the relative isolation of indigenous groups in pre-Columbus Mexico (MorenoEstrada et al., 2014), and even the possibility of interbreeding between humans and other humanoid groups such as Neandertals (Sankararaman, Patterson, Li, Pääbo, \& Reich, 
2012). Indeed, individual interest in one's own 'genetic history' is presumably a key driver in the market success of direct-to-consumer genetics testing. This genetic diversity is a scientific treasure of the highest order, but it also will require extremely careful study given that genetics and history are so intertwined.

In certain cases, the study of genetic differences can yield useful information regarding why the life trajectories of otherwise similar people diverge. Genetic differences may be a viable means for understanding divergent outcomes between individuals who otherwise have comparable starting points, such as siblings (although, even in this relatively simple case, there is complexity (Dunn \& Plomin, 1990)). In contrast, we argue that attempts to use genetic differences to explain variation in complex traits between individuals or groups that experience manifestly unequal environments is a fraught endeavor. Such an enterprise is, at the very least, technically challenging (Martin et al., 2017), and population geneticists have advised towards caution in this regard ("Letters," 2014). This is not to deny the existence of genetic differences. Human genetic variation undoubtedly exists, and genetic differences do occur between those from different ancestral backgrounds (The 1000 Genomes Project Consortium, 2012). That said, it will be nearly impossible to isolate the effects of genetic differences from the effects of environmental differences given both the severe levels of socioeconomic stratification that we observe in most societies across groups and the fact that many of the key group differences (e.g., between racial groups) are associated with dramatic differences in the ways we experience our environments (e.g., Gaddis, 2014).

Further complicating matters, ancestral differences should not be conflated with race. Ancestry, as geneticists use the term, refers to an individual's place in the many 
branching lines of genealogical descent. While humans all share the same, expansive family tree, ancestry captures genetic similarities of individuals due to more recent common forebearers. Ancestry is thus an individual characteristic that is captured in a person's DNA while race refers to a complex social process that ascribes individuals to socially-constructed groups or certain geographic areas (Yudell, Roberts, DeSalle, \& Tishkoff, 2016). Critically, the correspondence between racial and ancestral groups is dynamic; social processes perpetually redefine racial identities within and across generations (B. Duncan \& Trejo, 2011) while lines of genetic ancestry remain fixed. The increase in intermarriage (Wang, 2012) will further complicate questions of race and ancestry and the difficulties these issues pose to genetic analysis.

While genetics offer a fascinating lens from which to observe human history (Han et al., 2017; Moreno-Estrada et al., 2014), it is just one lens. Context matters. Using genetic differences as mechanisms for explaining group differences in traits that are highly contextualized — such as educational attainment—is inflammatory and stretches existing empirical evidence quite thin. Genetic differences between ancestral groups are likely small relative to the differences in environmental exposures which we know to be sizeable (Baradaran, 2017; Browning et al., 2017; Clark, Millet, \& Marshall, 2014). Furthermore, adequate study designs would be incredibly difficult to actually implement (Conley \& Fletcher, 2017, Ch. 5). In the case of complex traits, we are highly sympathetic to the disquiet that many social scientists experience for genetic explanations of trait differences between ancestral groups or, worse yet, racial groups. In particular, we see little value in pursuing such lines of inquiry pertaining to cognition and educational attainment. That said, others may not be dissuaded; racist and deterministic 
interpretations of genetics research into human behavior have existed for some time and remain a concern.

\section{5b. Unequal access to precision services}

If personalization of medicine or education only becomes precise for certain groups of people, it runs the risk of becoming a driver of inequality rather than a systemic means to improve public health. Although this is slowly changing (Wojcik et al., 2017), minority and indigenous populations are underrepresented in research samples and datasets (Bustamante, Francisco, \& Burchard, 2011; L. Duncan et al., 2018; Knerr, Wayman, \& Bonham, 2011). We emphasize two key points. First, individuals of European ancestry capture only a small amount of the total genetic diversity that exists in humans. Northern Europe, for example, is quite genetically homogeneous, meaning that an individual from Denmark (in terms of ancestry) and another from Norway are likely to be more genetically similar than two Nigerians living a few miles from each other (Li et al., 2008; Rosenberg \& Kang, 2015). These collections of genetically homogeneous data have limited methodological strengths for some purposes, but they do not offer information that necessarily generalizes to all humans. Second, misdeeds of previous generations may have led to certain populations being cautious of engagement with biomedical research. For example, the Tuskegee experiment led to substantial mistrust of the medical community (Alsan \& Wanamaker, 2017). Perhaps as a consequence of such experiences, there is reduced enrollment in genotyping efforts amongst African Americans (Bogner et al., 2004; McQuillan, Pan, \& Porter, 2006).

The relative homogeneity of the samples from whom most genetic information is drawn leads to a risk that any benefits (should there be any) of genotyping (e.g., 
personalized medicine) will accrue to already privileged groups (Popejoy \& Fullerton, 2016). For example, there are concerns that prescription drug dosage guidelines may need to vary across ancestral groups, partially as a function of differences in certain allele frequencies (Burroughs, Maxey, \& Levy, 2002; Evans, 1999; "Genes, drugs and race," 2001). This is not a simple issue and the lack of diverse genetic data will hamper our ability to make decisions about where such refinements are needed. An additional concern is that, at present, predictive performance of polygenic scores is typically maximal in those of European ancestry (L. Duncan et al., 2018), which is to be expected given the composition of discovery samples (Scutari, Mackay, \& Balding, 2016). Going back to the original motivating example, genetic tests for early identification of learning disabilities that only have clinical relevance for European-descent individuals would exacerbate existing disparities in issues associated with identification of those entitled to special education services, an issue we discuss in more detail below.

Even if equivalent information can be derived from genetic data for all people, there are additional reasons for concern. As the commercialization of genetics advances, policy makers and educators will have to consider the implications of genetic testing (conducted both inside and outside of schools) for equity. Higher income people generally tend to respond more quickly to new health-related information (Link, Northridge, Phelan, \& Ganz, 1998). Decreasing costs have made genetic information accessible to the everyday American, resulting in a market for consumer genetics. Getting genotyped has quickly become a popular way for individuals to discover more about themselves and their family history in a relatively inexpensive manner. Such access to consumer genetics has the potential to widen class and race disparities in education if 
information derived from genotyping becomes available largely to families with sufficient means. Or, such information may only be actionable in certain schools that have the proper resources to tailor interventions. If this is the case, consumer genetics could further divide the opportunities available to students from different social and economic backgrounds.

Inequality due to differential access to genetic screening is particularly unsettling as prenatal genetic screening has the potential to translate social inequality into genetic differences. It is already common practice for families to conduct genetic testing in-utero to detect disorders like Down syndrome, cystic fibrosis, and Tay-Sachs disease (Péter, 2015). Moreover, parents utilizing in vitro fertilization can choose to select for specific attributes, like the sex of their child (Baruch, Kaufman, \& Hudson, 2008). Perhaps this will evolve such that parents with the means and resources go beyond simply screening their children for learning disabilities and choose to also screen unborn children for socially-valued traits like cognitive functioning or athleticism. As we begin to better understand the genetic basis for a wider range of characteristics, differential access to such screening practices could create new gaps in the genetic risks for a variety of valued life outcomes across social strata. Socioeconomic gaps in genetic risk could serve to strain the role that the public education system plays in equalizing opportunities across individuals.

An alternative concern is the potential for discrimination based on genotype. Consider the possibility of insurance rate setting as a function of genotype. This already happens to a certain extent in countries like the United Kingdom (Godard et al., 2004). In the United States, the Genetic Information Nondiscrimination Act (GINA) of 2008 makes 
it currently illegal to discriminate for health insurance based on genotype ("The Genetic Information Nondiscrimination Act," 2009). However, the law does not offer protections for long-term care, disability, or life insurance, creating a loophole for genetic discrimination. As scientific and technological advancements continue, researchers and policy makers will have to proactively collaborate to prevent genetic discrimination in access to not only healthcare but possibly educational environments too. An over-reliance on genetic information could create systems that constrict rather than expand educational opportunity.

\section{5c. Learning Disabilities}

An increased capacity for inexpensive identification of developmental disorders at younger ages could be transformative for children who have learning disabilities. Genetics are one component in the etiology of many of these conditions such as dyslexia (Carrion-Castillo, Franke, \& Fisher, 2013), ADHD (Middeldorp et al., 2016), and autism (de la Torre-Ubieta, Won, Stein, \& Geschwind, 2016). Due to the plummeting cost of genotyping and the increasing predictive power of polygenic scores, the implementation of a genetic screening system could transform our approach to managing learning disabilities from reactive to proactive. In the most optimistic scenario, children with preclinical symptoms who might have gone unnoticed could receive the extra help they need sooner or those who have been misdiagnosed might be placed in an environment to which they are better suited. Such systems would require resolution of a variety of challenges. For example, there are arguments regarding the degree to which genetic influences associated with learning disabilities are general rather than disease-specific (Plomin \& Kovas, 2005), thus raising the question about disease-specific genetic screenings. Even if 
individual-level screening remains impractical, it's also possible that genetics may be a useful tool here for refinement of disease nosology; work in this arena is beginning to occur with respect to psychiatric conditions (Anttila et al., 2018; S. H. Lee et al., 2013) and may ultimately be of interest in studies of learning disability. We anticipate this to be an active area of research given the prospect of clinical utility of genetic prediction for other medical conditions (Torkamani, Wineinger, \& Topol, 2018),

Aside from clinical prediction, a better understanding of the distribution of various genetic risks across schools could be used to study inequities in the current ways the educational system under- and over-diagnoses students. For example, research could use polygenic scores to compare the relationship between genetic risk and diagnosis for neurodevelopmental disorders across school-age individuals in a population, thereby identifying differential diagnoses and treatment across groups. Such screenings may add useful data — specifically, indicators with some degree of objectivity — to the existing debate regarding whether children from marginalized groups (e.g., economically disadvantaged students (Sullivan \& Bal, 2013), English language learners (Sullivan, 2011)) are overrepresented in special education. Should genetics provide actionable information - which, we stress, is an open question given the difficulties associated with constructing clinically relevant genetic predictors in diverse samples—school systems might be better able to determine which students would benefit from certain education support services and interventions. 


\section{Specific Recommendations}

Below we provide two actionable recommendations for researchers with interest and/or concerns in genetics and education research that we think might serve to minimize the negative consequences for equity.

\section{6a. Refrain from overly broad claims}

In most cases, scientific discovery leads to a gradual accumulation of knowledge and preliminary findings can be contradicted by later work. One doesn't have to go far afield to observe this phenomenon given the candidate gene era's failure to identify replicable genetic variants associated with characteristics such as intelligence (Chabris et al., 2012). Due to its uniquely sensitive role in discourses regarding social inequality and individual differences, those in the field of genetics must help to avoid the repetition of previous mistakes by responsibly tempering claims as they pertain to education. In particular, research needs be attentive to the structural realities that underlie many observed educational differences between groups (Callier \& Bonham, 2015; Parens \& Appelbaum, 2015); findings should be grounded in the appropriate contexts and interpretations that acknowledge these realities should be favored.

However, it may be that such well-grounded research is not enough. As education is a topic relevant to nearly all Americans, such responsible research should also be reliably disseminated to the media and the general public. One potential exemplar in this regard is the work of the SSGAC, a genetics research consortium that brings together social scientists, molecular geneticists, and bioethicists. Their papers, especially their discovery work on the genetics of educational attainment (Okbay et al., 2016; Rietveld et al., 2013), are all accompanied by carefully worded online "FAQs" which are meant to 
offer context and clarity for interpreting their findings. This practice has been framed as "the best example of prophylaxis against hyperbole" (Parens \& Appelbaum, 2015). They give clear guidance against overly simplistic interpretations of their findings: "Did you find 'the gene' for cognitive performance? No.” (Social Science Genetic Association Consortium, n.d.). Researchers at the intersection of genetics and education would do well to work hard to explicitly spell out what their results do and do not entail, both to their academic peers and the public at large.

\section{6b. Encourage adversarial collaboration}

Conversations regarding the role of genetics in education are ongoing in both the biomedical and social sciences. However, thus far, little has been done to foster a conversation between the two. We are talking past, instead of with, each other. Now is the time for collaborative interdisciplinary research. We argue, along with others (Rose, 2013), that researchers should aim for critical engagement in place of the existing critical distance between these two research communities. Those interested in bringing genetic information into education ought to think critically about how to conduct socially responsible work that recognizes the socioeconomic and racial inequity inherent within the United States. Without considering contextual factors, implanting genetics research into education runs the risk of normalizing group differences in educational outcomes. Collaboration with social scientists studying systemic inequality from a qualitativeoriented perspective may help foster interdisciplinary approaches to genetically-informed research. Participants in this form of 'adversarial collaboration' are engaging with disciplines that are frequently seen as at odds with each other and will presumably continue to have differences in opinion (Kahneman, 2003). Such collaborations are not 
driven by a focus on short-term results; rather, the goal is to encourage processes that lead to a richer understanding of a particular subject or issue.

\section{Conclusion}

Let's return to the scenario posed at the beginning of this paper: you are a school administrator grappling with a request for early reading support for a child whose parent claims is at heightened genetic risk for dyslexia. It is too early for any authoritative answer to the central question — what do you do? — but we have attempted to point educators to a more tractable question: What will you want to know? In particular, we have tried to sketch out the relevant issues one must consider to answer this question by focusing on the possibilities and limitations of research utilizing molecular genetics.

To be clear, we do not advocate for any specific usage of molecular data in schools. Rather, we hope that this review of the growing body of molecular genetics findings relevant to education may begin to orient people towards key points in this rapidly evolving field. We offer a quick reiteration of some of the most important questions, focusing specifically on genetic predictors derived from molecular genetic data. How predictive are genetics for the question at hand and how consistent is prediction across the kinds of groups that typically co-occur with educational inequality? What specific features of the learner in question are being predicted? At present, the available genetic predictors are fairly broad but more targeted genetic prediction may become available over time. Finally, what are the implications of using genetic predictors for equity? Can all children take advantage of any useful diagnostic information that becomes available? To further complicate matters, there will be continuous need for monitoring the consequences of including such information in research and practice. 
We close by focusing on the question of equity. As genetics increases in salience across scientific domains and public life, we advocate for critical and open conversation between policy makers, educators, and researchers. In order to ensure genetics research benefits all and not just some, regulation meant to safeguard privacy and equal treatment will be increasingly important. Spaces for academic debate and engagement with the American public on issues pertaining to genetically-informed research are already opening (Columbia University, 2013; Emanuel, 1998; Personal Genetics Education Project, n.d.; University of California San Francisco, n.d.). Expanding the conversation to encourage adversarial collaboration and public awareness will prove critical for enacting regulations that keep equity in mind.

The floodgates of genetic data have opened. It is our opinion that education will undoubtedly be affected. When should genetic data be used? What regulations should be put in place? These are challenging questions that demand informed engagement. How we as researchers engage with these new developments to proactively combat the use of genetically-informed research for racist, classist, or inequitable purposes, will be of the utmost importance. 


\section{References}

Alsan, M., \& Wanamaker, M. (2017). Tuskegee and the Health of Black Men. The Quarterly Journal of Economics, 133(1), 407-455.

Asbury, K. (2015). Can Genetics Research Benefit Educational Interventions for All?, 45.

Retrieved from http://onlinelibrary.wiley.com/doi/10.1002/hast.497/abstract

Asbury, K., Almeida, D., Hibel, J., Harlaar, N., \& Plomin, R. (2008). Clones in the classroom: A daily diary study of the nonshared environmental relationship between monozygotic twin differences in school experience and achievement. Twin Research and Human Genetics, $11(6), 586-595$.

Asbury, K., Dunn, J. F., \& Plomin, R. (2006). Birthweight-discordance and differences in early parenting relate to monozygotic twin differences in behaviour problems and academic achievement at age 7. Developmental Science, 9(2).

Asbury, K., \& Plomin, R. (2013). G is for Genes: the Impact of Genetics on Education and Achievement. Retrieved from http://search.lib.cam.ac.uk/?itemid=|cambrdgedb|5600098

Baradaran, M. (2017). The Color of Money: Black Banks and the Racial Wealth Gap. Harvard University Press.

Barcellos, S. H., Carvalho, L. S., \& Turley, P. (2018). Education can Reduce Health Disparities Related to Genetic Risk of Obesity: Evidence from a British Reform. BioRxiv, 260463.

Barth, D., Papageorge, N. W., \& Thom, K. (2018). Genetic Endowments and Wealth Inequality. National Bureau of Economic Research.

Baruch, S., Kaufman, D., \& Hudson, K. L. (2008). Genetic testing of embryos: practices and perspectives of US in vitro fertilization clinics. Fertility and Sterility, 89(5), 1053-1058. https://doi.org/https://doi.org/10.1016/j.fertnstert.2007.05.048

Bates, T. C., Maher, B. S., Medland, S. E., McAloney, K., Wright, M. J., Hansell, N. K., ... Gillespie, N. A. (2018). The Nature of Nurture: Using a Virtual-Parent Design to Test 
Parenting Effects on Children's Educational Attainment in Genotyped Families. Twin Research and Human Genetics, 21(2), 73-83.

Belsky, D., Domingue, B., Wedow, R., Arseneault, L., Boardman, J., Caspi, A., ... Harris, K. M. (2018). Genetic analysis of social-class mobility in five longitudinal studies. Proceedings of the National Academy of Sciences. https://doi.org/10.1073/pnas.1801238115

Belsky, D., \& Israel, S. (2014). Integrating genetics and social science: Genetic risk scores. Biodemography and Social Biology, 60(2), 137-155.

Belsky, D. W., Caspi, A., Arseneault, L., Corcoran, D., Domingue, B. W., Harris, K. M., ... others. (2018). Genetics \& the Geography of Health, Behavior, and Attainment. BioRxiv, 376897.

Belsky, D. W., Moffitt, T., Corcoran, D., Domingue, B., Harrington, H., Hogan, S., ... Capsi, A. (2016). The genetics of success: How SNPs associated with educational attainment relate to life course development. Psychological Science.

Belsky, D. W., Moffitt, T. E., \& Caspi, A. (2013). Genetics in Population Health Science: Strategies and Opportunities. American Journal of Public Health, 103(S1), S73-S83. https://doi.org/10.2105/AJPH.2012.301139

Binet, A. (1913). A method of measuring the development of the intelligence of young children, (2d ed.). Chicago, Ill.,: Chicago medical book co.

Boardman, J. D., Daw, J., \& Freese, J. (2013). Defining the environment in gene-environment research: lessons from social epidemiology. American Journal of Public Health, 103(S1), S64-S72.

Bogner, H. R., Wittink, M. N., Merz, J. F., Straton, J. B., Cronholm, P. F., Rabins, P. V., \& Gallo, J. J. (2004). Personal characteristics of older primary care patients who provide a buccal swab for apolipoprotein E testing and banking of genetic material: the spectrum study. Community Genetics, 7(4), 202-210. https://doi.org/10.1159/000082263 
Boyle, E. A., Li, Y. I., \& Pritchard, J. K. (2017). An Expanded View of Complex Traits: From Polygenic to Omnigenic. Cell, 169(7), 1177-1186.

Branigan, A. R., McCallum, K. J., \& Freese, J. (2013). Variation in the heritability of educational attainment: An international meta-analysis. Social Forces, 92(1), 109-140.

Brigham, C. C. (1922). A Study of American Intelligence. Princeton: Princeton University Press.

Browning, C. R., Calder, C. A., Ford, J. L., Boettner, B., Smith, A. L., \& Haynie, D. (2017). Understanding racial differences in exposure to violent areas: integrating survey, smartphone, and administrative data resources. The Annals of the American Academy of Political and Social Science, 669(1), 41-62.

Burroughs, V. J., Maxey, R. W., \& Levy, R. A. (2002). Racial and ethnic differences in response to medicines: towards individualized pharmaceutical treatment. Journal of the National Medical Association, 94(10 Suppl), 1-26.

Bustamante, C. D., Francisco, M., \& Burchard, E. G. (2011). Genomics for the world. Nature, 475(7355), 163-165.

Byrne, B., Coventry, W. L., Olson, R. K., Samuelsson, S., Corley, R., Willcutt, E. G., ... DeFries, J. C. (2009). Genetic and environmental influences on aspects of literacy and language in early childhood: Continuity and change from preschool to Grade 2. Journal of Neurolinguistics, 22(3), 219-236. https://doi.org/10.1016/j.jneuroling.2008.09.003

Callier, S. L., \& Bonham, V. L. (2015). Taking a Stand: The Genetics Community’s Responsibility for Intelligence Research. Hastings Center Report, 45(S1), S54-S58. https://doi.org/10.1002/hast.500

Carrion-Castillo, A., Franke, B., \& Fisher, S. E. (2013). Molecular Genetics of Dyslexia: An Overview. Dyslexia, 19(4), 214-240. https://doi.org/10.1002/dys.1464

Caspi, A., McClay, J., Moffitt, T. E., Mill, J., Martin, J., Craig, I. W., ... Poulton, R. (2002). Role of genotype in the cycle of violence in maltreated children. Science, 297(5582), 851-854. 
Cesarini, D., \& Visscher, P. M. (2017). Genetics and educational attainment. Npj Science of Learning, 2(1), 4. https://doi.org/10.1038/s41539-017-0005-6

Chabris, C. F., Hebert, B. M., Benjamin, D. J., Beauchamp, J., Cesarini, D., van der Loos, M., ... Laibson, D. (2012). Most Reported Genetic Associations with General Intelligence Are Probably False Positives. Psychological Science, 23(11), 1314-1323. https://doi.org/10.1177/0956797611435528

Chabris, C. F., Lee, J. J., Cesarini, D., Benjamin, D. J., \& Laibson, D. I. (2015). The fourth law of behavior genetics. Current Directions in Psychological Science, 24(4), 304-312.

Clark, L. P., Millet, D. B., \& Marshall, J. D. (2014). National patterns in environmental injustice and inequality: outdoor NO2 air pollution in the United States. PloS One, 9(4), e94431.

Columbia University. (2013). Center for Research on Ethical, Legal \& Social Implications of Psychiatric, Neurologic \& Behavioral Genetics. Retrieved November 14, 2017, from http://braingenethics.cumc.columbia.edu/education-and-training/elsi-researchdevelopment-services/

Conley, D. (2016). Socio-Genomic Research Using Genome-Wide Molecular Data. Annual Review of Sociology, 42(1), 275-299. https://doi.org/10.1146/annurev-soc-081715074316

Conley, D., Domingue, B., Cesarini, D., Dawes, C., Rietveld, C., \& Boardman, J. (2015). Is the Effect of Parental Education on Offspring Biased or Moderated by Genotype? Sociological Science, 2, 82-105. https://doi.org/10.15195/v2.a6

Conley, D., \& Fletcher, J. (2017). The Genome Factor: What the social genomics revolution reveals about ourselves, our history, and the future. Princeton, New Jersey: Princeton University Press.

Dalsgaard, S., Østergaard, S. D., Leckman, J. F., Mortensen, P. B., \& Pedersen, M. G. (2015). Mortality in children, adolescents, and adults with attention deficit hyperactivity disorder: 
a nationwide cohort study. The Lancet, 385(9983), 2190-2196.

https://doi.org/10.1016/S0140-6736(14)61684-6

de la Torre-Ubieta, L., Won, H., Stein, J. L., \& Geschwind, D. H. (2016). Advancing the understanding of autism disease mechanisms through genetics. Nature Medicine, 22(4), 345-361. https://doi.org/10.1038/nm.4071

de Zeeuw, E. L., van Beijsterveldt, C. E. M., Glasner, T. J., Bartels, M., Ehli, E. A., Davies, G. E., ... Boomsma, D. I. (2014). Polygenic scores associated with educational attainment in adults predict educational achievement and ADHD symptoms in children. American Journal of Medical Genetics Part B: Neuropsychiatric Genetics, 165(6), 510-520. https://doi.org/10.1002/ajmg.b.32254

Demontis, D., Walters, R. K., Martin, J., Mattheisen, M., Als, T. D., Agerbo, E., ... Neale, B. M. (2017). Discovery Of The First Genome-Wide Significant Risk Loci For ADHD. BioRxiv, 145581. https://doi.org/10.1101/145581

Devlin, B., Fienberg, S. E., Resnick, D. P., \& Roeder, K. (2013). Intelligence, Genes, and Success: Scientists Respond to The Bell Curve. Springer Science \& Business Media.

Domingue, B. W., \& Belsky, D. W. (2017). The social genome: Current findings and implications for the study of human genetics. PLoS Genetics, 13(3), e1006615.

Domingue, B. W., Belsky, D. W., Conley, D., Harris, K. M., \& Boardman, J. D. (2015).

Polygenic Influence on Educational Attainment. AERA Open, 1(3), 2332858415599972. https://doi.org/10.1177/2332858415599972

Domingue, B. W., Belsky, D. W., Fletcher, J. M., Conley, D., Boardman, J. D., \& Harris, K. M. (2018). The social genome of friends and schoolmates in the National Longitudinal Study of Adolescent to Adult Health. Proceedings of the National Academy of Sciences, 201711803. https://doi.org/10.1073/pnas.1711803115

Dudbridge, F. (2013). Power and Predictive Accuracy of Polygenic Risk Scores. PLOS Genetics, 9(3), e1003348. https://doi.org/10.1371/journal.pgen.1003348 
Duncan, B., \& Trejo, S. J. (2011). Intermarriage and the intergenerational transmission of ethnic identity and human capital for Mexican Americans. Journal of Labor Economics, 29(2), 195-227.

Duncan, L. E., \& Keller, M. C. (2011). A Critical Review of the First 10 Years of Candidate Gene-by-Environment Interaction Research in Psychiatry. American Journal of Psychiatry, 168(10), 1041-1049. https://doi.org/10.1176/appi.ajp.2011.11020191

Duncan, L., Shen, H., Gelaye, B., Ressler, K., Feldman, M., Peterson, R., \& Domingue, B. (2018). Analysis of Polygenic Score Usage and Performance across Diverse Human Populations. BioRxiv, 398396.

Dunn, J., \& Plomin, R. (1990). Separate lives: Why siblings are so different. Basic Books.

Emanuel, E. J. (1998). The blossoming of bioethics at NIH. Kennedy Institute of Ethics Journal, $8(4), 455-466$.

Evans, W. E. (1999). Pharmacogenomics: Translating Functional Genomics into Rational Therapeutics. Science, 286(5439), 487-491. https://doi.org/10.1126/science.286.5439.487

Feldman, M. W., \& Lewontin, R. C. (1975). The heritability hang-up. Science, 190(4220), 11631168. https://doi.org/10.1126/science. 1198102

Figlio, D. N., Freese, J., Karbownik, K., \& Roth, J. (2017). Socioeconomic status and genetic influences on cognitive development. Proceedings of the National Academy of Sciences, 201708491.

Fowler, J. H., \& Dawes, C. T. (2008). Two Genes Predict Voter Turnout. The Journal of Politics, 70(3), 579-594. https://doi.org/10.1017/S0022381608080638

Franke, B., Faraone, S. V., Asherson, P., Buitelaar, J., Bau, C. H. D., Ramos-Quiroga, J. A., ... International Multicentre persistent ADHD CollaboraTion. (2012). The genetics of attention deficit/hyperactivity disorder in adults, a review. Molecular Psychiatry, 17(10), 960-987. https://doi.org/10.1038/mp.2011.138 
Freese, J. (2018). The Arrival of Social Science Genomics. Contemporary Sociology, 47(5), 524536. https://doi.org/10.1177/0094306118792214a

Gaddis, S. M. (2014). Discrimination in the credential society: an audit study of race and college selectivity in the labor market. Social Forces, 93(4), 1451-1479.

Galton, F. (1869). Hereditary Genius: an Inquiry Into Its Laws and Consequences. Macmillan.

Galton, F. (1891). Hereditary Genius: An Inquiry Into Its Laws and Consequences (New and rev. ed., with an American preface.). New York: D. Appleton.

Genes, drugs and race. (2001). Nature Genetics, 29(3), 239-240. https://doi.org/10.1038/ng1101239

Gillborn, D. (2016). Softly, softly: genetics, intelligence and the hidden racism of the new geneism. Journal of Education Policy, 31(4), 365-388.

Gizer, I. R., Ficks, C., \& Waldman, I. D. (2009). Candidate gene studies of ADHD: a metaanalytic review. Human Genetics, 126(1), 51-90. https://doi.org/10.1007/s00439-0090694-x

Godard, B., Raeburn, S., Pembrey, M., Bobrow, M., Farndon, P., \& Aymé, S. (2004). Genetic information and testing in insurance and employment: technical, social and ethical issues. European Journal of Human Genetics, $11(\mathrm{~S} 2), 5201117$. https://doi.org/10.1038/sj.ejhg.5201117

Goldberger, A. S. (1979). Heritability. Economica, 46(184), 327-347.

Greenfield, P. M., Ward, L. M., \& Jacobs, J. (1997). You can't take it with you: why ability assessments don’t cross cultures. American Psychologist, 52(10), 1115-1124.

Gulson, K. N., \& Baker, B. M. (2018). New biological rationalities in education. Discourse: Studies in the Cultural Politics of Education, 39(2), 159-168. https://doi.org/10.1080/01596306.2017.1422077 
Gulson, K. N., \& Webb, P. T. (2017). Emerging Biological Rationalities for Policy: (Molecular) Biopolitics and the New Authorities in Education. In Policy and Inequality in Education (pp. 23-39). Springer, Singapore. https://doi.org/10.1007/978-981-10-4039-9_3

Gulson, K. N., \& Webb, P. T. (2018). 'Life' and education policy: intervention, augmentation and computation. Discourse: Studies in the Cultural Politics of Education, 39(2), 276-291. https://doi.org/10.1080/01596306.2017.1396729

Han, E., Carbonetto, P., Curtis, R. E., Wang, Y., Granka, J. M., Byrnes, J., .. Ball, C. A. (2017). Clustering of 770,000 genomes reveals post-colonial population structure of North America. Nature Communications, 8, 14238. https://doi.org/10.1038/ncomms14238

Harden, K. P. (2018, July 28). Opinion | Why Progressives Should Embrace the Genetics of Education. The New York Times. Retrieved from https://www.nytimes.com/2018/07/24/opinion/dna-nature-genetics-education.html

Harris, S. (2017, April 22). Forbidden Knowledge. Waking Up. Retrieved from https://samharris.org/podcasts/forbidden-knowledge/

Heckman, J. J. (1995). Lessons from the Bell Curve. Journal of Political Economy, 103(5), 10911120. https://doi.org/10.1086/262014

Heckman, J. J. (2011). The American Family in Black \& White: A Post-Racial Strategy for Improving Skills to Promote Equality. Daedalus, 140(2), 70-89.

Herrnstein, R. J., \& Murray, C. (2010). Bell Curve: Intelligence and Class Structure in American Life. Simon and Schuster.

Hewitt, J. K. (2012). Editorial Policy on Candidate Gene Association and Candidate Gene-byEnvironment Interaction Studies of Complex Traits. Behavior Genetics, 42(1), 1-2. https://doi.org/10.1007/s10519-011-9504-z

Hill, W. D., Davies, G., McIntosh, A. M., Gale, C. R., \& Deary, I. J. (2017). A combined analysis of genetically correlated traits identifies 107 loci associated with intelligence. BioRxiv, 160291. https://doi.org/10.1101/160291 
Hunt, J. (1864). The Negro's Place in Nature: A Paper Read Before the London Anthropological Society. Van Evrie, Horton.

Immordino-Yang, M. H., Darling-Hammond, L., \& Krone, C. (2018). The Brain Basis for Integrated Social, Emotional, and Academic Development. National Commission on Social, Emotional, and Academic Development.

Ioannidis, J. P. A., Ntzani, E. E., Trikalinos, T. A., \& Contopoulos-Ioannidis, D. G. (2001). Replication validity of genetic association studies. Nature Genetics, 29(3), 306-309. https://doi.org/10.1038/ng749

Jencks, C., \& Phillips, M. (2011). The Black-White Test Score Gap. Brookings Institution Press.

Jenkins, M. D. (1939). The Mental Ability of the American Negro. The Journal of Negro Education, 8(3), 511-520. https://doi.org/10.2307/2292647

Jensen, A. R. (1968). Social Class, Race, and Genetics: Implications for Education. American Educational Research Journal, 5(1), 1-42. https://doi.org/10.3102/00028312005001001

Jensen, A. R. (1969). How Much Can We Boost IQ and Scholastic Achievement. Harvard Educational Review, 39(1), 1-123. https://doi.org/10.17763/haer.39.1.13u15956627424k7

Jensen, A. R. (1970). Race and the Genetics of Intelligence: A Reply to Lewontin. Bulletin of the Atomic Scientists, 26(5), 17-23. https://doi.org/10.1080/00963402.1970.11457807

Kahn, J., Nelson, A., Graves, J. L. J., Abel, S., Benjamin, R., Blacker, S., ... Roberts, D. (2018, March 30). Opinion: How Not To Talk About Race And Genetics. Retrieved April 4, 2018, from https://www.buzzfeed.com/bfopinion/race-genetics-david-reich

Kahneman, D. (2003). Experiences of collaborative research. American Psychologist, 58(9), $723-$ 730. https://doi.org/10.1037/0003-066X.58.9.723

Kegel, C. A., Bus, A. G., \& van IJzendoorn, M. H. (2011). Differential susceptibility in early literacy instruction through computer games: The role of the dopamine D4 receptor gene (DRD4). Mind, Brain, and Education, 5(2), 71-78. 
Klein, E. (2018, March 27). Sam Harris, Charles Murray, and the allure of race science. Retrieved March 30, 2018, from https://www.vox.com/policy-andpolitics/2018/3/27/15695060/sam-harris-charles-murray-race-iq-forbidden-knowledgepodcast-bell-curve

Knerr, S., Wayman, D., \& Bonham, V. L. (2011). Inclusion of Racial and Ethnic Minorities in Genetic Research: Advance the Spirit by Changing the Rules? The Journal of Law, Medicine \& Ethics : A Journal of the American Society of Law, Medicine \& Ethics, 39(3), 502-512. https://doi.org/10.1111/j.1748-720X.2011.00617.x

Kong, A., Thorleifsson, G., Frigge, M. L., Vilhjalmsson, B. J., Young, A. I., Thorgeirsson, T. E., ... others. (2018). The nature of nurture: Effects of parental genotypes. Science, $359(6374), 424-428$.

Kovas, Y., Tikhomirova, T., Selita, F., Tosto, M. G., \& Malykh, S. (2016). How Genetics Can Help Education. In Y. Kovas, S. Malykh, \& D. Gaysina (Eds.), Behavioural Genetics for Education (pp. 1-23). Palgrave Macmillan UK. https://doi.org/10.1057/9781137437327_1

Krapohl, E., \& Plomin, R. (2015). Genetic link between family socioeconomic status and children's educational achievement estimated from genome-wide SNPs. Molecular Psychiatry.

Krapohl, E., Rimfeld, K., Shakeshaft, N. G., Trzaskowski, M., McMillan, A., Pingault, J.-B., ... Plomin, R. (2014). The high heritability of educational achievement reflects many genetically influenced traits, not just intelligence. Proceedings of the National Academy of Sciences, 111(42), 15273-15278. https://doi.org/10.1073/pnas.1408777111

Lander, E. S., Linton, L. M., Birren, B., Nusbaum, C., Zody, M. C., Baldwin, J., ... Morgan, M. J. (2001). Initial sequencing and analysis of the human genome. Nature, 409(6822), 860921. https://doi.org/10.1038/35057062 
Lee, J. J., Wedow, R., Okbay, A., Kong, E., Maghzian, O., Zacher, M., ... Cesarini, D. (2018). Gene discovery and polygenic prediction from a genome-wide association study of educational attainment in 1.1 million individuals. Nature Genetics, 50(8), 1112-1121. https://doi.org/10.1038/s41588-018-0147-3

Letters: 'A Troublesome Inheritance.' (2014, August 8). The New York Times. Retrieved from https://www.nytimes.com/2014/08/10/books/review/letters-a-troublesomeinheritance.html

Li, J. Z., Absher, D. M., Tang, H., Southwick, A. M., Casto, A. M., Ramachandran, S., ... Myers, R. M. (2008). Worldwide Human Relationships Inferred from Genome-Wide Patterns of Variation. Science, 319(5866), 1100-1104. https://doi.org/10.1126/science.1153717

Link, B. G., Northridge, M. E., Phelan, J. C., \& Ganz, M. L. (1998). Social Epidemiology and the Fundamental Cause Concept: On the Structuring of Effective Cancer Screens by Socioeconomic Status. Milbank Quarterly, 76(3), 375-402. https://doi.org/10.1111/14680009.00096

Linnér, R. K., Marioni, R., Rietveld, C., Simpkin, A., Davies, N., Watanabe, K., ... others. (2017). An epigenome-wide association study meta-analysis of educational attainment. Molecular Psychiatry, 22(12), 1680.

Marioni, R. E., Ritchie, S. J., Joshi, P. K., Hagenaars, S. P., Okbay, A., Fischer, K., ... Benjamin, D. J. (2016). Genetic variants linked to education predict longevity. Proceedings of the National Academy of Sciences, 201605334. https://doi.org/10.1073/pnas.1605334113

Martin, A. R., Gignoux, C. R., Walters, R. K., Wojcik, G. L., Neale, B. M., Gravel, S., .. Kenny, E. E. (2017). Human Demographic History Impacts Genetic Risk Prediction across Diverse Populations. American Journal of Human Genetics, 100(4), 635-649. https://doi.org/10.1016/j.ajhg.2017.03.004

Mayo, M. J. (1913). The mental capacity of the American negro. New York city. Retrieved from http://archive.org/details/mentalcapacityof00mayorich 
McQuillan, G. M., Pan, Q., \& Porter, K. S. (2006). Consent for genetic research in a general population: an update on the National Health and Nutrition Examination Survey experience. Genetics in Medicine: Official Journal of the American College of Medical Genetics, 8(6), 354-360. https://doi.org/10.109701.gim.0000223552.70393.08

Middeldorp, C. M., Hammerschlag, A. R., Ouwens, K. G., Groen-Blokhuis, M. M., St. Pourcain, B., Greven, C. U., ... Boomsma, D. I. (2016). A Genome-Wide Association MetaAnalysis of Attention-Deficit/Hyperactivity Disorder Symptoms in Population-Based Pediatric Cohorts. Journal of the American Academy of Child \& Adolescent Psychiatry, 55(10), 896-905.e6. https://doi.org/10.1016/j.jaac.2016.05.025

Moreno-Estrada, A., Gignoux, C. R., Fernández-López, J. C., Zakharia, F., Sikora, M., Contreras, A. V., ... Bustamante, C. D. (2014). The genetics of Mexico recapitulates Native American substructure and affects biomedical traits. Science, 344(6189), 1280-1285. https://doi.org/10.1126/science.1251688

Mõttus, R., Realo, A., Vainik, U., Allik, J., \& Esko, T. (2017). Educational Attainment and Personality Are Genetically Intertwined. Psychological Science, 28(11), 1631-1639. https://doi.org/10.1177/0956797617719083

National Human Genome Research Institute. (2016, July 6). The Cost of Sequencing a Human Genome. Retrieved October 20, 2017, from https://www.genome.gov/27565109/TheCost-of-Sequencing-a-Human-Genome

Neisser, U., Boodoo, G., Bouchard, T. J., Boykin, A. W., Brody, N., Ceci, S. J., ... Susana Urbina. (1996). Intelligence: Knowns and unknowns. American Psychologist. Vol. 51(2), $51,77-101$.

Okbay, A., Beauchamp, J. P., Fontana, M. A., Lee, J. J., Pers, T. H., Rietveld, C. A., ... Benjamin, D. J. (2016). Genome-wide association study identifies 74 loci associated with educational attainment. Nature, 533(7604), 539-542. https://doi.org/10.1038/nature17671 
Ozernov-Palchik, O., \& Gaab, N. (2016). Tackling the 'dyslexia paradox': reading brain and behavior for early markers of developmental dyslexia. Wiley Interdisciplinary Reviews: Cognitive Science, 7(2), 156-176. https://doi.org/10.1002/wcs.1383

Panofsky, A. (2015). What Does Behavioral Genetics Offer for Improving Education? Hastings Center Report, 45(S1), S43-S49. https://doi.org/10.1002/hast.498

Parens, E., \& Appelbaum, P. S. (2015). An Introduction to Thinking about Trustworthy Research into the Genetics of Intelligence. Hastings Center Report, 45(S1), S2-S8. https://doi.org/10.1002/hast.491

Payton, A., Holmes, J., Barrett, J. H., Hever, T., Fitzpatrick, H., Trumper, A. L., ... others. (2001). Examining for association between candidate gene polymorphisms in the dopamine pathway and attention-deficit hyperactivity disorder: A family-based study. American Journal of Medical Genetics Part A, 105(5), 464-470.

Pearson, T. A., \& Manolio, T. A. (2008). How to Interpret a Genome-wide Association Study. JAMA, 299(11), 1335-1344. https://doi.org/10.1001/jama.299.11.1335

Personal Genetics Education Project. (n.d.). pgEd - Personal Genetics Education Project. Retrieved November 14, 2017, from https://pged.org/

Péter, K. (2015). Prenatal Genetic Screening. In H. ten Have (Ed.), Encyclopedia of Global Bioethics (pp. 1-8). Springer International Publishing. https://doi.org/10.1007/978-3-31905544-2_346-1

Pickersgill, M., Niewöhner, J., Müller, R., Martin, P., \& Cunningham-Burley, S. (2013). Mapping the new molecular landscape: social dimensions of epigenetics. New Genetics and Society, 32(4), 429-447.

Plomin, R., \& Kovas, Y. (2005). Generalist genes and learning disabilities. Psychological Bulletin, 131(4), 592. 
Polderman, T. J., Benyamin, B., De Leeuw, C. A., Sullivan, P. F., Van Bochoven, A., Visscher, P. M., \& Posthuma, D. (2015). Meta-analysis of the heritability of human traits based on fifty years of twin studies. Nature Genetics, 47(7), 702.

Popejoy, A. B., \& Fullerton, S. M. (2016). Genomics is failing on diversity. Nature News, 538(7624), 161. https://doi.org/10.1038/538161a

Reich, D. (2018, March). How Genetics Is Changing Our Understanding of 'Race.' The New York Times. Retrieved from https://www.nytimes.com/2018/03/23/opinion/sunday/geneticsrace.html

Rietveld, C. A., Medland, S. E., Derringer, J., Yang, J., Esko, T., Martin, N. W., ... Koellinger, P. D. (2013). GWAS of 126,559 Individuals Identifies Genetic Variants Associated with Educational Attainment. Science, 340(6139), 1467-1471.

https://doi.org/10.1126/science. 1235488

Rimfeld, K., Krapohl, E., Trzaskowski, M., Coleman, J. R., Selzam, S., Dale, P. S., .. Plomin, R. (2018). Genetic influence on social outcomes during and after the Soviet era in Estonia. Nature Human Behaviour, 1.

Rosa, J., \& Bonilla, Y. (2017). Deprovincializing Trump, decolonizing diversity, and unsettling anthropology. American Ethnologist, 44(2), 201-208. https://doi.org/10.1111/amet.12468

Rose, N. (2013). The human sciences in a biological age. Theory, Culture \& Society, 30(1), 3-34.

Rosenberg, N. A., \& Kang, J. T. L. (2015). Genetic Diversity and Societally Important Disparities. Genetics, 201(1), 1-12. https://doi.org/10.1534/genetics.115.176750

Rushton, J. P., \& Jensen, A. R. (2006). The Totality of Available Evidence Shows the Race IQ Gap Still Remains. Psychological Science, 17(10), 921-922.

Sabatello, M. (2018). A Genomically Informed Education System? Challenges for Behavioral Genetics. The Journal of Law, Medicine \& Ethics, 46(1), 130-144. https://doi.org/10.1177/1073110518766027 
Saletan, W. (2018, April 27). Stop Talking About Race and IQ. Take It From Someone Who Did. Retrieved April 28, 2018, from https://slate.com/news-and-politics/2018/04/stop-talkingabout-race-and-iq-take-it-from-someone-who-did.html

Sankararaman, S., Patterson, N., Li, H., Pääbo, S., \& Reich, D. (2012). The date of interbreeding between Neandertals and modern humans. PLoS Genetics, 8(10), e1002947.

Scarr-Salapatek, S. (1971). Race, social class, and IQ. Science, 174(4016), 1285-1295.

Scutari, M., Mackay, I., \& Balding, D. (2016). Using genetic distance to infer the accuracy of genomic prediction. PLoS Genetics, 12(9), e1006288.

Selzam, S., Krapohl, E., von Stumm, S., O’Reilly, P. F., Rimfeld, K., Kovas, Y., ... Plomin, R. (2016). Predicting educational achievement from DNA. Molecular Psychiatry. https://doi.org/10.1038/mp.2016.107

Shockley, W. (1971). Negro IQ Deficit: Failure of a "Malicious Coincidence" Model Warrants New Research Proposals. Review of Educational Research, 41(3), 227-248. https://doi.org/10.2307/1169529

Shockley, W. (1972). Dysgenics, Geneticity, Raceology: A Challenge to the Intellectual Responsibility of Educators. The Phi Delta Kappan, 53(5), 297-307.

Sniekers, S., Stringer, S., Watanabe, K., Jansen, P. R., Coleman, J. R. I., Krapohl, E., ... Posthuma, D. (2017). Genome-wide association meta-analysis of 78,308 individuals identifies new loci and genes influencing human intelligence. Nature Genetics, 49(7), 1107-1112. https://doi.org/10.1038/ng.3869

Social Science Genetic Association Consortium. (n.d.). FAQs about "Genome-wide association study identifies 74 loci associated with educational attainment.” Retrieved October 20, 2017, from https://www.thessgac.org/faqs

Soden Hensler, B., Schatschneider, C., Taylor, J., \& Wagner, R. K. (2010). Behavioral Genetic Approach to the Study of Dyslexia. Journal of Developmental and Behavioral Pediatrics : JDBP, 31(7), 525-532. https://doi.org/10.1097/DBP.0b013e3181ee4b70 
Sternberg, R. J., \& Grigorenko, E. L. (2004). Intelligence and culture: how culture shapes what intelligence means, and the implications for a science of well-being. Philosophical Transactions-Royal Society of London Series B Biological Sciences, 1427-1434.

Sullivan, A. L. (2011). Disproportionality in Special Education Identification and Placement of English Language Learners. Exceptional Children, 77(3), 317-334.

Sullivan, A. L., \& Bal, A. (2013). Disproportionality in Special Education: Effects of Individual and School Variables on Disability Risk. Exceptional Children, 79(4), 475-494. https://doi.org/10.1177/001440291307900406

Terman, L. M. (1916). The measurement of intelligence: An explanation of and a complete guide for the use of the Stanford revision and extension of the Binet-Simon intelligence scale. Houghton Mifflin.

The 1000 Genomes Project Consortium. (2012). An integrated map of genetic variation from 1,092 human genomes. Nature, 491(7422), 56-65. https://doi.org/10.1038/nature11632

The Genetic Information Nondiscrimination Act: A First Step Toward Protecting Americans From Misuse of Genetic Information. (2009). Journal of Oncology Practice, 5(1), 40-41. https://doi.org/10.1200/JOP.0912504

Thomas, M. S. C., Kovas, Y., Meaburn, E. L., \& Tolmie, A. (2015). What Can the Study of Genetics Offer to Educators? Mind, Brain, and Education, 9(2), 72-80. https://doi.org/10.1111/mbe.12077

Torkamani, A., Wineinger, N. E., \& Topol, E. J. (2018). The personal and clinical utility of polygenic risk scores. Nature Reviews Genetics, 1.

Trampush, J. W., Yang, M. L. Z., Yu, J., Knowles, E., Davies, G., Liewald, D. C., ... Lencz, T. (2017). GWAS meta-analysis reveals novel loci and genetic correlates for general cognitive function: a report from the COGENT consortium. Molecular Psychiatry, 22(3), 336-345. https://doi.org/10.1038/mp.2016.244 
Trejo, S., Belsky, D. W., Boardman, J. D., Freese, J., Harris, K. M., Herd, P., ... Domingue, B. W. (2018). Schools as Moderators of Genetic Associations with Life Course Attainments: Evidence from the WLS and Add Heath. Sociological Science, 5, 513-540. https://doi.org/10.15195/v5.a22

Tucker-Drob, E. M., \& Bates, T. C. (2016). Large cross-national differences in gene X socioeconomic status interaction on intelligence. Psychological Science, 27(2), 138-149.

Turkheimer, E. (1991). Individual and group differences in adoption studies of IQ. Psychological Bulletin, 110(3), 392-405. https://doi.org/10.1037/0033-2909.110.3.392

Turkheimer, E. (2000). Three laws of behavior genetics and what they mean. Current Directions in Psychological Science, 9(5), 160-164.

Turkheimer, E., Haley, A., Waldron, M., D’Onofrio, B., \& Gottesman, I. I. (2003). Socioeconomic status modifies heritability of iq in young children. Psychological Science, 14, 623-628. https://doi.org/10.1046/j.0956-7976.2003.psci_1475.x

Turkheimer, E., Harden, K. P., \& Nisbett, R. E. (2017, May 18). Charles Murray is once again peddling junk science about race and IQ. Retrieved April 4, 2018, from https://www.vox.com/the-big-idea/2017/5/18/15655638/charles-murray-race-iq-samharris-science-free-speech

Ukkola, L. T., Onkamo, P., Raijas, P., Karma, K., \& Järvelä, I. (2009). Musical Aptitude Is Associated with AVPR1A-Haplotypes. PLOS ONE, 4(5), 1-10. https://doi.org/10.1371/journal.pone.0005534

University of California San Francisco. (n.d.). Center for Transdisciplinary ELSI Research in Translational Genomics. Retrieved November 14, 2017, from http://www.ct2g.org/

Visscher, P. M., Brown, M. A., McCarthy, M. I., \& Yang, J. (2012). Five Years of GWAS Discovery. American Journal of Human Genetics, 90(1), 7-24. https://doi.org/10.1016/j.ajhg.2011.11.029 
Visscher, P. M., Hill, W. G., \& Wray, N. R. (2008). Heritability in the genomics era-concepts and misconceptions. Nature Reviews Genetics, 9(4), 255.

Visscher, P. M., Wray, N. R., Zhang, Q., Sklar, P., McCarthy, M. I., Brown, M. A., \& Yang, J. (2017). 10 Years of GWAS Discovery: Biology, Function, and Translation. American Journal of Human Genetics, 101(1), 5-22. https://doi.org/10.1016/j.ajhg.2017.06.005

Wade, N. (2014). A Troublesome Inheritance: Genes, Race and Human History (Second Printing edition). New York: Penguin Press.

Wang, W. (2012). The rise of intermarriage. Washington, DC: Pew Research Center. Retrieved August, 13, 2012.

Wedow, R., Zacher, M., Huibregtse, B., Harris, K. M., Domingue, B., \& Boardman, J. (2018). Education, Smoking, and Cohort Change: Forwarding a Multidimensional Theory of the Environmental Moderation of Genetic Effects. American Sociological Review, 83(4), $802-832$.

Williamson, B., Pykett, J., \& Nemorin, S. (2018). Biosocial spaces and neurocomputational governance: brain-based and brain-targeted technologies in education. Discourse: Studies in the Cultural Politics of Education, 39(2), 258-275.

https://doi.org/10.1080/01596306.2018.1394421

Wojcik, G., Graff, M., Nishimura, K. K., Tao, R., Haessler, J., Gignoux, C. R., ... Carlson, C. S. (2017). Genetic Diversity Turns a New PAGE in Our Understanding of Complex Traits. BioRxiv, 188094. https://doi.org/10.1101/188094

Youdell, D. (2017). Bioscience and the sociology of education: the case for biosocial education. British Journal of Sociology of Education, 38(8), 1273-1287. https://doi.org/10.1080/01425692.2016.1272406

Youdell, D. (2018). Genetics, Epigenetics and Social Justice in Education: Learning as a Complex Biosocial Phenomenon. In The Palgrave Handbook of Biology and Society (pp. 295-315). Palgrave Macmillan, London. https://doi.org/10.1057/978-1-137-52879-7_13 
Yudell, M., Roberts, D., DeSalle, R., \& Tishkoff, S. (2016). Taking race out of human genetics. Science, 351(6273), 564-565. https://doi.org/10.1126/science.aac4951

Zabaneh, D., Krapohl, E., Gaspar, H. A., Curtis, C., Lee, S. H., Patel, H., ... Breen, G. (2017). A genome-wide association study for extremely high intelligence. Molecular Psychiatry. https://doi.org/10.1038/mp.2017.121 